\title{
Thrombolysis with low dose tissue plasminogen activator
}

\author{
E Doyle, J Britto, J Freeman, F Munro, N S Morton
}

\begin{abstract}
Two cases of vena caval thrombosis in infants were successfully treated with low dose $(0.01-0.05 \mathrm{mg} / \mathrm{kg} / \mathrm{hour})$ local infusions of tissue plasminogen activator after conventional anticoagulant treatment had been unsuccessful. This approach is useful for clots associated with indwelling intravascular catheters, and a low dose infusion of tissue plasminogen activator as a regional application is recommended to achieve clot lysis with minimal systemic effects.
\end{abstract}

(Arch Dis Child 1992;67:1483-4)

Recombinant tissue plasminogen activator has been used in adults for thrombolysis after myocardial infarction. ${ }^{1}$ There is little experience of its use in children and there are no dose recommendations. Two cases of vena caval thrombosis in infants are reported here in which conventional anticoagulant treatment was unsuccessful but which were successfully treated with low dose $(0.01-0.05 \mathrm{mg} / \mathrm{kg} /$ hour $)$ local infusions of tissue plasminogen activator.

\section{Case reports}

CASE 1

A neuroblastoma was removed from a 13 month old boy. A Hickman line was sited in the left internal jugular vein to administer chemotherapy. Two weeks later he develoepd oedema and venous congestion of the face, neck, and arms. An ultrasound examination showed obstruction of the superior vena cava and a diagnosis of superior vena caval thrombosis was made.

Treatment was started with an infusion of heparin at $25 \mathrm{IU} / \mathrm{kg} /$ hour following a bolus of $100 \mathrm{IU} / \mathrm{kg}$. There was no clinical improvement after 24 hours. A venogram showed an extensive thrombus filling the left subclavian and innominate veins extending into the superior vena cava.

An infusion of recombinant tissue plasminogen activator was started through the Hickman line at a dose of $0.01 \mathrm{mg} / \mathrm{kg} / \mathrm{hour}$. This was increased to $0.05 \mathrm{mg} / \mathrm{kg} / \mathrm{hour}$ after four hours, and after $\mathbf{2 4}$ hours of treatment improvement in the swelling and oedema was noted. An ultrasound examination showed blood flow through the innominate veins and superior vena cava.

After 48 hours of treatment there was some bleeding from the Hickman line insertion site. The infusion of tissue plasminogen activator was stopped for three hours and restarted at $0.03 \mathrm{mg} / \mathrm{kg} /$ hour. No further bleeding was seen. After three days of treatment the tissue plasminogen activator infusion was stopped, the
Hickman line removed, and a heparin infusion started. During treatment fibrinogen was measured daily and was always greater than 3.5 $\mathrm{g} / \mathrm{l}$. The concentration of the D-dimer during treatment was between 0.2 and $4 \mathrm{mg} / \mathrm{l}$.

\section{CASE 2}

A male infant was born with transposition of the great arteries and had an atrial septostomy on the first day of life. This was followed one week later by a switch operation with reimplantation of the coronary arteries. His clinical course after the operation was complicated by persistent bilateral chylothoraces and he needed albumin and total parenteral nutrition via the central venous cannulae. Four weeks after the operation a clinical diagnosis of superior vena caval thrombosis was made and confirmed by venography. During this period there had been continuous cannulation of the superior vena cava by several different catheters inserted by different routes. The child was treated with an intravenous infusion of heparin and then warfarin by mouth to achieve an internationalised normal ratio of $2 \cdot 0-2 \cdot 5$.

Six weeks after the operation an ultrasound examination of the inferior vena cava showed a large thrombus extending from the tip of a right femoral vein catheter and occupying most of the inferior vena cava. Warfarin was discontinued and recombinant tissue plasminogen activator given through the femoral vein catheter at an initial dose of $0.01 \mathrm{mg} / \mathrm{kg} / \mathrm{hour}$. This was increased to $0.02 \mathrm{mg} / \mathrm{kg} / \mathrm{hour}$ after six hours and was continued for six days. Serial ultrasound examinations showed complete lysis of the clot over this period. The infant was then treated with an intravenous infusion of heparin followed by warfarin by mouth.

There was no bleeding during the infusion of tissue plasminogen activator. The fibrinogen concentration was always greater than $1.5 \mathrm{~g} / 1$ and the D-dimer concentration between 0.2 and $4 \mathrm{mg} / \mathrm{l}$.

\section{Discussion}

Tissue plasminogen activator is a naturally occurring protein which plays a part in the fibrinolytic cascade. It catalyses the conversion of the inactive proenzyme plasminogen into the active serine protease plasmin. Tissue plasminogen activator has a high affinity for fibrin and the tissue plasminogen activator-fibrin complex enhances the binding of plasminogen to fibrin. This fibrin bound plasminogen is broken down to produce plasmin locally at the site of the clot. This clot selective mechanism, together with the low affinity of tissue plasminogen activator 
for circulating plasminogen, is thought to minimise the systemic thrombolytic effects of tissue plasminogen activator.

Bleeding may be reduced by the regional application of tissue plasminogen activator directly onto the clot with the assumption that the thrombolytic effect will be entirely local. This is attractive for clots associated with indwelling intravascular catheters which may be used as the treatment route.

Our two patients received a low dose infusion of tissue plasminogen activator as a regional application to try to achieve clot lysis with minimal systemic effects.

A similar low dose $(0.05 \mathrm{mg} / \mathrm{kg} / \mathrm{hour})$ regional infusion of tissue plasminogen activator has been used in four neonates with caval thrombosis secondary to indwelling intravascular catheters. ${ }^{2}$ There was successful lysis of the clot in three of the patients. In one patient the infusion caused a decrease in fibrinogen concentrations and an increase in fibrin degradation products and this infant had an intraventricular haemorrhage.

When higher doses of tissue plasminogen activator $(0 \cdot 1-0.5 \mathrm{mg} / \mathrm{kg} /$ hour $)$ were given to 12 children, ${ }^{3}$ six had bleeding complications. In these six patients bleeding was associated with a tissue plasminogen activator dose of $0.46-0.50$ $\mathrm{mg} / \mathrm{kg} /$ hour)

The age of the clot to be lysed has an important effect on its susceptibility to thrombolysis. Most in vivo studies suggest that clots become more resistant to lysis as they age. ${ }^{4}$
Early initiation of treatment is important and this may have been a factor in the success of the low doses of tissue plasminogen activator reported here.

Although pharmacologically effective doses of tissue plasminogen activator appear to cause less of a systemic lytic effect than streptokinase, ${ }^{5}$ there is a poor correlation between markers of systemic thrombolysis and bleeding complications. $^{6}$

In view of the limited experience with the use of tissue plasminogen activator in children and the fact that these patients are likely to have a relatively high incidence of catheter associated thrombosis, our patients indicate that local application of low dose $(0.01-0.05 \mathrm{mg} / \mathrm{kg} /$ hour $)$ infusions may be a useful approach.

1 Wilcox RG, von der Lippe G, Olssen CG, Jensen G, Skene AM, Hampton JR. Trial of tissue plasminogen activator for mortality reduction in acute myocardial infarction. AngloScandinavian Study of Early Thrombolysis (ASSET). Lancet 1988;ii:525-9.

2 Anderson BJ, Keeley SR, Johnson ND. Caval thrombolysis in neonates using low doses of recombinant human tissuetype plasminogen activator. Anaesth Intensive Care 1991;19: 22-7.

3 Levy M, Benson LN, Burrows PE, et al. Tissue plasminogen activator for the treatment of thromboembolism in infants activator for the treatment of thromboem
and children. F Pediatr 1991;118:467-72.

4 Marder VJ, Sherry S. Thrombolytic therapy: current status. NEngl , Shed 1988:318:1585-95.

5 Naylor CD, Armstrong PD. Guidelines for the use of intravenous thrombolytic agents in acute myocardial infarction. Can Med Assoc F 1989;140:1289-99.

6 Mueller HS, Rao AK, Forman MA, et al. Thrombolysis in myocardial infarction (TIMI): comparative studies of coronary reperfusion and systemic fibrinogenolysis with two forms of recombinant tissue-type plasminogen activator. f Am Coll Cardiol 1987;10:479-90.

\section{Fatal encephalitis/encephalopathy in primary human herpesvirus- 6 infection}

\author{
Department of \\ Paediatrics, \\ Fujita Health University \\ School of Medicine \\ Y Asano \\ T Yoshikawa \\ S Suga \\ T Yazaki \\ T Nakashima \\ Department of \\ Paediatrics, \\ Kariya Sogo Hospital \\ Y Kajita \\ R Ogura \\ Department of \\ Microbiology, \\ Kyoto Prefectural \\ University School \\ of Medicine \\ A Yamada \\ Department of \\ Pathology, \\ National Institute \\ of Health \\ T Kurata \\ Correspondence to: \\ Dr Y Asano, \\ Department of Pediatrics, \\ Fujita Health University \\ School of Medicine, \\ School of \\ Aichi 470-11 \\ Japan. \\ Accepted 13 July 1992
}

Y Asano, T Yoshikawa, Y Kajita, R Ogura, S Suga, T Yazaki, T Nakashima, A Yamada, T Kurata

\begin{abstract}
An encephalitic illness with a fatal outcome occurred in a 9 month old girl with virologically confirmed exanthem subitum. Human herpesvirus-6 (HHV-6) DNA was found in the cerebrospinal fluid at the acute stage of the disease by the polymerase chain reaction, but the virus antigen was not detected in her brain tissue. This suggests that HHV-6-induced encephalitis/encephalopathy may be due to a non-infectious process.
\end{abstract}

(Arch Dis Child 1992;67:1484-5)

Central nervous system complications are well known during the course of exanthem subitum, which is caused by primary infection with human herpesvirus-6 (HHV-6). It has been strongly suggested that the virus invades the central nervous system and causes encephalitis or encephalopathy. ${ }^{2}$ There is, however, little information on whether the virus invades the brain tissue. We report a fatal case of exanthem subitum with encepalitic illness that occurred in the pre-eruptive stage of the disease. The virological and histopathological findings of the case are also presented.

\section{Case report}

A 9 month old girl was admitted to the Kariya Sogo Hospital because of high fever and generalised clonic convulsions. She had been apparently well until the afternoon of the previous day (day 0 ) when her temperature had suddenly risen to $39 \cdot 2^{\circ} \mathrm{C}$. In the early hours of the next morning she had a generalised clonic convulsion that persisted for one minute; this occurred approximately 10 times during the next four hours. She vomited several times and became drowsy and was admitted to our hospital suffering from stupor that morning (day 1). On admission, physical examination revealed a well nourished, well developed infant with a normal anterior fontanelle. She had been born at full term after an uncomplicated pregnancy. Her 